ఠ

\title{
mTOR inhibitor in the treatment of Hodgkin's lymphoma: a case report
}

This article was published in the following Dove Press journal:

Blood and Lymphatic Cancer:Targets and Therapy

7 November 2011

Number of times this article has been viewed

\section{Patricia lbeas \\ Blanca Cantos \\ Mariano Provencio \\ Clinical Oncology Department, Hospital Puerta de Hierro Majadahonda, Madrid, Spain}

Correspondence: Patricia lbeas Clinical Oncology Department, Hospital Puerta de Hierro Majadahonda, Calle Joaquín Rodrigo, 2, 28222 Madrid, Spain Tel +34911916000 Fax +34 91 191 6671

Email patoibeas@hotmail.com
Abstract: Hodgkin's disease is curable in $90 \%$ of the cases diagnosed in early stages (I and II) and in $70 \%$ of all patients who suffer from the disease. Refractory disease occurs in $10 \%-15 \%$ of cases and is still a clinical challenge. Its treatment is based on intensive chemotherapy regimens with transplantation, but there are patients who relapse after transplantation who have a poor prognosis. At this point in time, there is a lack of effective treatment options with proven efficacy and there is a real need to investigate new treatment drugs with different mechanisms of action. A persistent activation of mTOR signaling has been identified in leukemia, Hodgkin's and non-Hodgkin's lymphoma, and multiple myeloma. Everolimus, an mTOR kinase inhibitor, is being used as an option in these cases with encouraging results. Here, the authors report their experience with a patient treated with everolimus.

Keywords: everolimus, positron emission tomography, chemotherapy

\section{Introduction}

With improvements in radiotherapy techniques and the development of anticancer drugs, Hodgkin's disease is curable in $90 \%$ of the cases diagnosed in early stages (I and II) and in $70 \%$ of all patients who suffer from the disease. Refractory disease, which is defined as failure to achieve a complete remission after first-line treatment, is a rare clinical situation occurring in only $10 \%-15 \%$ of cases, which remains a clinical challenge.

Treatment of refractory Hodgkin's disease includes the application of intensive chemotherapy regimens with hematopoietic rescue; however, the median survival of these cohorts is around 16 months. A small percentage of patients $(10 \%-20 \%)$ have prolonged survival after transplantation. Patients who relapse after transplantation have a poor prognosis. There is a clear need to investigate new drugs with different mechanisms of action due to a lack of treatment options with proven efficacy. Thus, this paper presents the authors' experience with a patient treated with everolimus.

The mammalian target of rapamycin (mTOR) is a serine/threonine kinase that exists as a downstream component of numerous signaling pathways. Persistent activation of mTOR signaling has been identified in cell lines and samples from patients with leukemia, Hodgkin's lymphoma, non-Hodgkin's lymphoma, and multiple myeloma. Hence, following these lines, the authors' experience with a patient treated with everolimus is reported here. ${ }^{1}$

\section{Case report}

A 27-year-old woman with no medical history of interest was diagnosed in 2004 with classical interfollicular Hodgkin's lymphoma with multiple supradiaphragmatic 
mediastinal bulky disease. Chemotherapy was initiated with adriamycin, bleomycin, vincristine, and dacarbazine for six cycles, ending in April 2005. Subsequently, radiotherapy was administered to the bulky mass, with a total dose of 40 Gy. A re-evaluation was performed after treatment using a computed tomography scan in September 2005. A mediastinal mass measuring $5.5 \times 3 \mathrm{~cm}$ and mediastinal nodes, with activity on positron emission tomography computed tomography, were apparent. A lymph-node biopsy confirmed the persistence of Hodgkin's lymphoma.

A second line of chemotherapy was given with the etoposide, corticosteroids, arabinofuranosyl cytidine, and cisplatin scheme, with three cycles administered between January and March 2006. A partial response was observed. In March 2006, a mini-BEAM (Bis-chloroethylnitrosourea $60 \mathrm{mg} / \mathrm{m}^{2}$ on day 1 , Etoposide $75 \mathrm{mg} / \mathrm{m}^{2}$ on days $2-5$, Ara-C $100 \mathrm{mg} / \mathrm{m}^{2}$ every 12 hours on days 2-5, Melphalan $30 \mathrm{mg} / \mathrm{m}^{2}$ on day 6) scheme was consolidated with autologous bonemarrow transplantation on March 24, 2006.

In August 2006, enlarged laterocervical adenopathies were detected, which were confirmed as viable supradiaphragmatic disease using positron emission tomography computed tomography.

The patient reported pain in her left leg, and magnetic resonance imaging showed an infiltration of the bone marrow, with a suppression of the L5 and a bulging of the rear wall into the spinal canal, stenosis of the right conjunction foramen of L5-S1, and a decrease of the right conjunction foramen of L4-L5. Radiotherapy with analgesic intention was administered, with a dose of $24 \mathrm{~Gy}$, from March 17 to 25, 2007. Because of tumor progression, three cycles of chemotherapy were given with the gemcitabine $750 \mathrm{mg} / \mathrm{m}^{2}$ and oxaliplatin $100 \mathrm{mg} / \mathrm{m}^{2}$ scheme from June to August 2007. A CT scan demonstrated a partial response of the mediastinal mass. A positron emission tomography scan showed supradiaphragmatic lymph node tumor viability. The patient refused to continue with active treatment and remained in remission.

In November 2008, a progression was observed at right axilla, as well as significant progression into the bone of the supraclavicular and right laterocervical nodes. The patient reported that the medial and distal left femur as well as the left humerus, left ischium, right femur, and L5 were causing pain. The patient began painkillers and started a new line of treatment with $5 \mathrm{mg}$ everolimus per day orally as compassionate use in September 2009. Upon evaluation, extensive partial response was present, with persisting deposits in the axillary lymphadenopathies and left humerus head that were low-intensity but with complete response in the laterocervical and mediastinal lymph nodes.

During this period, antalgic radiotherapy at the femoral lesion was provided.

Figures 1 and 2 show an important decrease of prevascular mediastinal involvement between March 2009 and April 2011, under everolimus.

The most recent re-evaluation occurred in June 2011, with a diagnosis of stable disease. The patient remains on $5 \mathrm{mg}$ everolimus, which is well tolerated. The only side effect noted was initial weight loss, which has been controlled with dietary supplements.

\section{Discussion}

Most patients with Hodgkin's lymphoma have complete remission of the disease after first-line chemotherapy treatment. However, up to $15 \%$ of stage I and II patients with a favorable prognosis ${ }^{2}$ and up to $40 \%$ of patients with advanced stage relapse. ${ }^{3}$

The relapse occurs within the first 12 months in half of these cases. ${ }^{4}$ A select group of patients with poor prognosis after the first or second relapse or those patients with refractory disease may benefit from bone marrow transplantation prior to induction with salvage chemotherapy regimens. Several clinical trials have shown that negative positron emission tomography scans before transplantation and after induction have a significant predictive value, with a progression-free survival at 2 years of $93 \% .^{5-7}$ Relapse after hematopoietic transplantation has a very poor prognosis, and there are no treatments with proven clinical efficacy in these situations; these patients are candidates for palliative treatments.

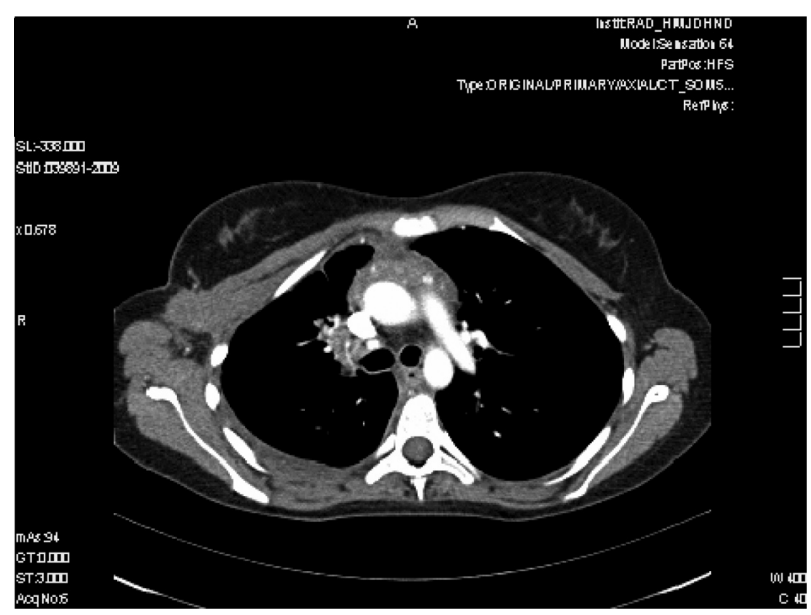

Figure I Computed tomograph scan of thorax-abdomen, March 7, 2009. Wide prevascular mediastinal involvement. 


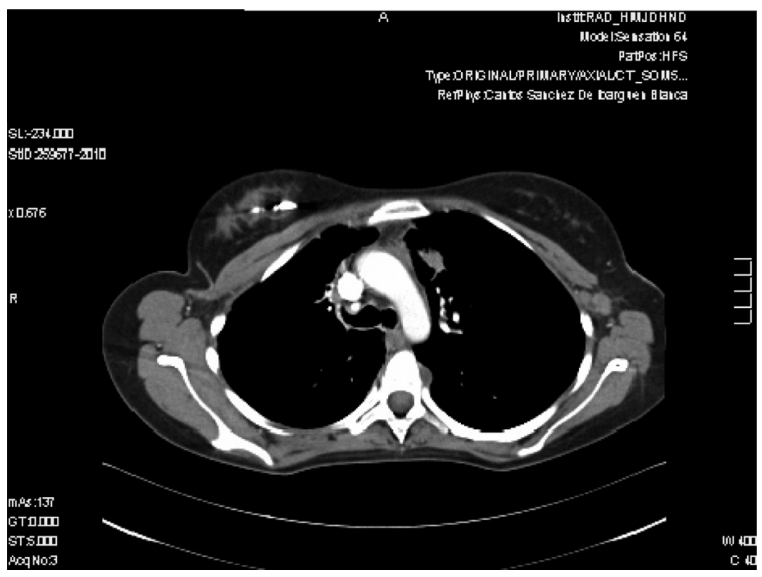

Figure 2 Computed tomograph scan of thorax-abdomen, April 6, 20II. Important decrease of prevascular mediastinal involvement.

Currently, the phosphatidylinositol 3-kinase (PI3K)/ protein kinase $\mathrm{B}(\mathrm{Akt}) / \mathrm{mTor}$ pathway is gaining importance as a therapeutic target. Several clinical trials have been conducted with mTOR inhibitors (see Table 1), such as everolimus, temsirolimus, and sirolimus. ${ }^{8-10}$ The basis for the use of this pathway is based on mTOR, a serine threonine kinase that plays a key role in regulating cell cycle progression, cell growth, and protein synthesis, through interactions with various signaling pathways such as PI3K/Akt, B-cell receptor/ V-abl Abelson murine leukemia viral oncogene homolog 1, rat sarcoma (Ras), and T-cell leukemia/lymphoma protein 1 . mTOR is composed of two components, mTORC1 and mTORC2. mTORC1 is inhibited by everolimus and its analogs because it is thought that mTORC2 is activated by routes other than PI3K/Akt. ${ }^{11}$ An important alteration of the PI3K/Akt pathway has been observed in hematological malignancies such as Hodgkin's lymphoma, which gives a rational basis for the use of these drugs. ${ }^{12}$
A persistent activation of mTOR signaling is observed in cell lines from Hodgkin's lymphoma, as well as diffuse large B-cell lymphoma and mantle lymphoma.

Some lymphomas express high levels of Ras homolog enriched in brain (Rheb), a Ras homolog that binds to tuberous sclerosis complex (TSC). When Akt is activated, Rheb is disassociated from TSC, resulting in the activation of TSC and thereby permitting its interaction with mTOR. Thus, the expression of Rheb is associated with increased activation of mTOR. ${ }^{1}$

Activation of PI3K is frequently associated with the deletion or mutation of phosphatase and tensin homolog (PTEN) in many tumors. However, in Hodgkin's lymphoma, other mechanisms activate the pathway, including activation of CD30, CD40, and Receptor Activator of Nuclear Factor $\kappa$ $\mathrm{B}$ receptors, mutations in the $\mathrm{p} 85 \mathrm{a}$ subunit of $\mathrm{PI} 3 \mathrm{~K}$ and inactivation of PTEN function through phosphorylation. CD40, a member of the tumor necrosis factor receptor family, is expressed on the surface of $\mathrm{B}$ cells, from pro-B to plasma cell stages. The inhibition of this line with antibodies to CD40 (SNG-40 and CHIR-12.12) results in apoptotic effects of antibody-dependent cellular cytotoxicity. ${ }^{13}$

In addition to its direct antitumor effect, everolimus and its family induce immune responses that enhance the clinical response by inhibiting angiogenesis. ${ }^{14}$ Cytostatic and cytotoxic effects have been demonstrated both in vivo and in vitro for malignant cells following treatment with everolimus. ${ }^{15}$ As shown in Table 1, which summarizes the existing clinical trials to date with everolimus, acceptable response rates have been observed, particularly when considering that this group has undergone a great amount of prior treatment. ${ }^{8-10}$ The highest rate of response was generally obtained in Hodgkin's lymphoma, when stratifying by subgroups.

Table I Trials with everolimus on Hodgkin's lymphoma

\begin{tabular}{|c|c|c|c|c|c|c|c|c|}
\hline Trial & Design & $\begin{array}{l}\text { Patients } \\
\text { (N) }\end{array}$ & $\begin{array}{l}\text { Histological } \\
\text { subtypes }\end{array}$ & $\begin{array}{l}\text { Median age } \\
\text { (years) }\end{array}$ & $\begin{array}{l}\text { Prior } \\
\text { therapies }\end{array}$ & $\begin{array}{l}\text { Complete } \\
\text { responses (\%) }\end{array}$ & $\begin{array}{l}\text { Partial } \\
\text { responses (\%) }\end{array}$ & $\begin{array}{l}\text { Time to } \\
\text { progression } \\
\text { (months) }\end{array}$ \\
\hline $\begin{array}{l}\text { Witzig } \\
\text { et al }{ }^{9}\end{array}$ & Phase II & 145 & $\begin{array}{l}77 \mathrm{NHL} \\
17 \mathrm{HL} \\
8 \text { lymph T } \\
41 \text { indolent lymph }\end{array}$ & NA & 4 & NA & $\begin{array}{l}33 \text { in all subgroups } \\
53 \text { in } \mathrm{HL}\end{array}$ & 4.3 \\
\hline $\begin{array}{l}\text { Johnston } \\
\text { et } \mathrm{al}^{8}\end{array}$ & Phase II & 19 & $\begin{array}{l}\text { HL I00\% } \\
16 \% \mathrm{I} / \mathrm{II} \\
84 \% \mathrm{III} / \mathrm{IV}\end{array}$ & 37 & 6 & 0 & 47 & 7.2 \\
\hline $\begin{array}{l}\text { Reeder } \\
\text { et } \mathrm{al}^{10}\end{array}$ & Phase II & 37 & $\begin{array}{l}20 \text { DLBCL } \\
\text { I } 4 \text { mantle } \\
2 \text { high grade } \\
\text { I folicullar }\end{array}$ & 72 & 4 & 2.7 & 29.7 & 5.5 \\
\hline
\end{tabular}

Abbreviations: NA, not available; HL, Hodgkin's lymphoma; NHL, non-Hodgkin's lymphoma; DLBCL, diffuse large B-cell lymphoma; lymph, lymphoma. 
Thus, the authors believe the improved response to everolimus in the patient discussed (the longest response maintained in the history of her disease) is due to the persistent activation of the mTOR signal that may be present in her tumor cells. A study by Johnston et $\mathrm{al}^{8}$ of patients with Hodgkin's lymphoma showed a time to progression of 7.2 months, which is shorter than the time to progression of the patient in the present study, who, at the time of writing, has a time to progression of 22 months and a good quality of life.

Future research is ongoing based on the combination of mTOR with conventional chemotherapy (eg, sorafenib, perifosine), with the goal of avoiding resistance to administered drugs that could increase efficacy by complementing the different mechanisms of action.

\section{Disclosure}

The authors declare no potential conflicts of interest relevant to this article.

\section{References}

1. Younes A, Samad N. Utility of mTOR inhibition in hematologic malignancies. Oncologist. 2011;16:730-741.

2. Specht L, Gray RG, Clarke MJ, Peto R. Influence of more extensive radiotherapy and adjuvant chemotherapy on long-term outcome of early-stage Hodgkin's disease: a meta-analysis of 23 randomized trials involving 3,888 patients. J Clin Oncol. 1998;16:830-843.

3. Viviani S, Bonadonna G, Santoro A, et al. Alternating versus hybrid MOPP and ABVD combinations in advanced Hodgkin's disease: ten-year results. J Clin Oncol. 1996;14(5):1421-1430.
4. Oza AM, Ganesan TS, Leahy M, et al. Patterns of survival in patients with Hodgkin's disease: long follow up in a single centre. Ann Oncol. 1993;4:385-392.

5. Castagna L, Bramanti S, Balzarotti M, et al. Predictive value of early $18 \mathrm{~F}$-fluorodeoxyglucose positron emission tomography (FDG-PET) during salvage chemotherapy in relapsing/refractory Hodgkin lymphoma (HL) treated with high-dose chemotherapy. Br J Haematol. 2009;145:369-372.

6. Schot BW, Zijlstra JM, Sluiter WJ, et al. Early FDG-PET assessment in combination with clinical risk scores determines prognosis in recurring lymphoma. Blood. 2007;109:486-491.

7. Jabbour E, Hosing C, Ayers G, et al. Pretransplant positive positron emission tomography/gallium scans predict poor outcome in patients with recurrent/refractory Hodgkin lymphoma. Cancer. 2007;109: 2481-2489.

8. Johnston PB, Inwards DJ, Colgan JP, et al. A Phase II trial of the oral mTOR inhibitor everolimus in relapsed Hodgkin lymphoma. Am J Hematol. 2010;85:320-324.

9. Witzig TE, Reeder CB, LaPlant BR, et al. A phase II trial of the oral mTOR inhibitor everolimus in relapsed aggressive lymphoma. Leukemia. 2011;25:341-347.

10. Reeder CB, Gornet MK, Habermann TM, et al. A phase II trial of the oral mTOR inhibitor everolimus (RAD001) in relapsed aggressive non-Hodgkin lymphoma (NHL). Blood. 2007;110:Abstract 121.

11. Reeder CB, Ansel SM. Novel therapeutic agents for B-cell lymphoma: developing rational combinations. Blood. 2011;117:1453-1462.

12. Witzig TE, Gupta M. Signal transduction inhibitor therapy for lymphoma. Hematology Am Soc Hematol Educ Program. 2010;2010:265-270.

13. Cheson BD, Leonard JP. Monoclonal antibody therapy for B-cell nonHodgkin's lymphoma. N Engl J Med. 2008;359:613-626.

14. Jona A, Younes A. Novel treatment strategies for patients with relapsed classical Hodgkin's lymphoma. Blood Rev. 2010;24:233-238.

15. Johnston PB, Yuan R, Cavalli F, Witzig TE. Targeted therapy in lymphoma. J Hematol Oncol. 2010;3:45.
Blood and Lymphatic Cancer: Targets and Therapy

\section{Publish your work in this journal}

Blood and Lymphatic Cancer: Targets and Therapy is an international, peer-reviewed, open access journal focusing on blood and lymphatic cancer research, identification of therapeutic targets and the optimal use of preventative and integrated treatment interventions to achieve improved outcomes, enhanced survival and quality of life for the

\section{Dovepress}

cancer patient. The manuscript management system is completely online and includes a very quick and fair peer-review system. Visit http://www.dovepress.com/testimonials.php to read real quotes from published authors. 